\title{
Analisa Pengujian Kelayakan Operasi Pemutus Tenaga (PMT) 150 kV Bay Penghantar Mandirancan I Berdasarkan Parameter Breaker Analyzer di Gardu Induk Sunyaragi
}

\author{
Adis Galih Firdaus $^{1}$, Rahmat Hidayat. ${ }^{2}$ \\ 1,2 Jurusan Teknik Elektro, Fakultas Teknik, Universitas Singaperbangsa Karawang, Karawang \\ Jl. H.S Ronggowaluyo, Telukjambe Timur, Karawang 41361 \\ 1 adis.galih17026astudent.unsika.ac.id \\ ${ }^{2}$ rahmat.hidayatestaff.unsika.ac.id
}

Intisari - Listrik merupakan sebuah energi yang sangat penting bagi segala aspek dalam kehidupan masyarakat. PT. PLN (Persero) sebagai penyedia dan pemasok energi listrik di Indonesia tentunya dituntut harus dapat mensuplai kebutuhan listrik bagi masyarakat dengan baik. Upaya yang dapat dilakukan untuk melakukan hal tersebut adalah memastikan kelayakan dan keandalan pada peralatan - peralatan yang terdapat dalam sistem transmisi tenaga listrik dengan melakukan pengujian dan pemeliharaan secara rutin dan teratur. Salah satu peralatan yang memiliki peran vital dalam sistem transmisi tenaga listrik adalah Pemutus Tenaga (PMT) karena fungsinya sebagai saklar mekanis yang harus dapat memutus aliran arus beban baik dalam kondisi normal maupun ketika terjadi gangguan pada saluran tenaga listrik sesuai dengan ratingnya yang berperan penting untuk melindungi peralatan lainnya dari kerusakan ketika terjadi gangguan. Oleh karena itu keandalan dari PMT ini harus selalu terjaga terutama waktu kerja kontak dari ketiga fasanya yang harus serempak ketika bekerja. Dimana pada penelitian ini akan dilakukan pengujian waktu kerja kontak PMT 150 kV Mandirancan I yang terdapat di Gardu Induk Sunyaragi dengan berdasarkan pada nilai parameter yang dihasilkan oleh Breaker Analyzer. Pengujian dilakukan sebanyak 4 kali percobaan dengan mengukur waktu kerja kontak open, close, reclose, dan OCO (Open - Close - Open). Hasil pengujian menunjukkan bahwa PMT ini memiliki anomali dalam hal keserempakan kontaknya, dimana salah satu kontaknya bekerja lebih cepat ketika menutup yang diakibatkan oleh tarikan motor yang lebih lama daripada kontak lainnya. Untuk mengatasi hal tersebut, dilakukanlah pengaturan ulang pada Motor Run Limit Switch PMT agar lama waktu motor ketika bekerja serupa di semua kontaknya. Kata kunci - Transmisi Tenaga Listrik, Pemutus Tenaga, Breaker Analyzer, Keserempakan, Motor.

Abstract - Electricity is an energy that is very important for all aspects of people's life. PT. PLN (Persero) as a provider and supplier of electrical energy in Indonesia, of course, is required to be able to supply electricity needs to the community properly. Efforts that can be made to do this are to ensure the appropriateness and reliability of the equipment contained in the electric power transmission system by carrying out routine and regular testing and maintenance. One of the equipment that has a vital role in the electric power transmission system is the Circuit Breaker (CB) because of its function as a mechanical switch that must be able to cut off the flow of the load current both in normal conditions and when there is a disturbance in the power line according to the rating which plays an important role in protecting other equipment from damage in the event of a breakdown. Therefore, the reliability of this $\mathrm{CB}$ must always be maintained, especially the contact working time of the three phases which must be synchronized when working. Where in this study will be carried out testing the contact working time of the $\mathrm{CB} 150 \mathrm{kV}$ Mandirancan I located at the Sunyaragi substation based on the parameter values generated by the Breaker Analyzer. The test was carried out 4 times by measuring the working time of open, close, reclose, and OCO (Open - Close - Open) contacts. The test results show that this CB has an anomaly in terms of the synchronization of its contacts, where one of the contacts works faster when it closes due to the longer motor pull than the other contacts. To overcome this, reset the Motor Run Limit Switch CB so that the length of time the motor works is similar in all its contacts.

Keywords - Electric Power Transmission, Circuit Breaker, Breaker Analyzer, Simultaneous, Motor. 


\section{PENDAHULUAN}

Listrik merupakan sebuah energi yang belakangan ini telah menjadi kebutuhan utama bagi kehidupan masyarakat baik di perkotaan maupun di pedesaan, segala aspek mulai dari perekonomian, transportasi, industri, pendidikan, hingga perkembangan teknologi semuanya tak lepas dari masalah dalam penggunaan energi listrik tersebut [1]. Hampir semua peralatan pendukung kehidupan sehari - hari kita juga menggunakan energi listrik sebagai sumber suplai utamanya, sehingga tentunya kebutuhan masyarakat akan energi listrik tersebut pasti akan terus meningkat [1]-[3]. Oleh karena itu, PT. PLN (Persero) selaku perusahaan utama penyedia dan pemasok energi listrik di Indonesia harus dapat bekerja mensuplai dengan baik kebutuhan energi listrik bagi masyarakat pada umumnya [4]. Dimana untuk memenuhi hal tersebut, maka dibangunlah sejumlah Pusat Pembangkit Listrik, Gardu Induk (GI), saluran transmisi dan saluran distribusinya sebagai media untuk menyalurkan aliran daya energi listrik hingga sampai pada masyarakat sebagai konsumennya [5].

Gardu Induk (GI) merupakan bagian dari sistem Transmisi Tenaga Listrik yang merupakan salah satu komponen penting dalam penyaluran energi listrik ke beberapa penyulang [10]. Gardu Induk ini memiliki fungsi utama yaitu untuk mengatur aliran daya listrik dan mentransformasikan tegangan yang datang dari Pusat Pembangkitan Listrik ke beberapa nilai tegangan yang diinginkan [10]. Dimana untuk melakukan fungsinya tersebut, Gardu Induk ini dibantu oleh berbagai macam peralatan, baik itu peralatan primer maupun peralatan sekunder [6].

Peralatan - peralatan tersebutlah yang berperan dalam proses penyaluran tenaga listrik di sebuah Gardu Induk, maka dari itu untuk tetap menjaga keandalan serta kelayakan operasi kerja dari peralatan yang digunakan perlu dilakukannya perawatan dan pemeliharaan serta pengujian secara rutin yang tentunya dengan pemeliharaan ini juga akan menambah umur masa pakai dari peralatan tersebut [5], [6].
Salah satu peralatan yang sangat penting dalam sebuah Gardu Induk (GI) untuk dilakukan pemeliharaan secara rutin adalah Circuit Breaker (CB), yang jika dalam bahasa Indonesianya disebut sebagai Pemutus Tenaga (PMT) [1]-[5]. CB atau PMT ini sangat penting peranannya karena PMT ini bekerja sebagai saklar mekanis yang harus dapat memutus aliran arus beban baik dalam kondisi normal maupun ketika terjadi gangguan pada saluran tenaga listrik sesuai dengan ratingnya yang berperan penting untuk melindungi peralatan lainnya dalam sistem transmisi di sebuah Gardu Induk [6].

Jadi ketika adanya sebuah gangguan seperti hubung singkat pada sistem transmisi di Gardu Induk, maka PMT akan bekerja membuka (open) kontaknya agar arus berlebih yang dihasilkan dari hubung singkat tersebut tidak sampai masuk merusak ke peralatan lainnya dalam sebuah bay (jalur) penghantar ataupun trafo [1]-[4], [6]. Oleh karena itu, apabila PMT sedang bermasalah dan kebetulan terjadi gangguan di sistem transmisinya, peralatan lainnya yang terdapat di dalam sebuah bay (jalur) tersebut akan terkena dampak dari arus berlebih yang dihasilkan sehingga dapat menyebabkan kerusakan pada peralatan tersebut [1]-[4], [6]

Rusaknya peralatan dalam sebuah Gardu Induk tentunya dapat menyebabkan penyaluran dan distribusi tenaga listrik terganggu, dengan demikian PMT ini sangat penting untuk dirawat dan dipelihara secara rutin dengan cara melakukan serangkaian pengujian pada PMT untuk menentukan kelayakan operasi kerja dari PMT tersebut, berdasarkan dari beberapa parameter pengujian yang dilakukan sesuai dengan standar yang telah ditentukan [1], [5]-[7].

Sehubungan dengan hal tersebut, maka dalam penelitian ini akan dilakukan evaluasi dari pemeliharaan rutin PMT yang dilakukan pada salah satu PMT yang terdapat di Gardu Induk Sunyaragi, tepatnya di bay (jalur) penghantar Mandirancan $1150 \mathrm{kV}$ Single Pole yang telah beroperasi dari tahun 1997 dan merupakan salah satu Pemutus Tenaga (PMT) yang sudah terbilang cukup tua. Fokus evaluasi yang dilakukan pada penelitian ini yaitu menganalisa salah satu pengujian penting yang dilakukan pada PMT 
mengenai keserempakan waktu tiap kontak PMT ketika bekerja [2]-[4], menggunakan sekumpulan data yang diambil berdasarkan nilai dari parameter yang dihasilkan oleh alat uji Breaker Analyzer [8].

\section{TINJAUAN PUSTAKA}

\section{A. Pemutus Tenaga (PMT)}

Pemutus tenaga merupakan salah satu peralatan yang memiliki peran sangat vital dalam sebuah Gardu Induk (GI) [1]-[5]. Pemutus Tenaga (PMT) sendiri memiliki pengertian yaitu sebagai sebuah peralatan dalam sistem transmisi tenaga listrik yang berfungsi sebagai saklar mekanis untuk bertindak sebagai pemutus aliran beban (arus listrik) ketika kondisi normal ataupun pada saat terjadi gangguan pada saluran sistem tenaga listrik sesuai dengan rating yang dimiliki oleh PMT tersebut agar tidak terjadi kerusakan [6]. PMT harus dapat berfungsi secara optimal, karena apabila terjadi sebuah gangguan seperti gangguan hubung singkat pada sistem transmisi di GI, PMT harus dapat dengan cepat memutus (open) kontaknya agar arus berlebih akibat hubung singkat tidak sampai masuk ke peralatan lainnya yang dapat menyebakan rusaknya peralatan tersebut [1]-[4], [6].

\section{B. Klasifikasi Pemutus Tenaga}

Klasifikasi Pemutus Tenaga dapat dibagi atas beberapa jenis, antara lain berdasarkan tegangan rating/nominal, jumlah mekanik penggerak, media isolasi, dan proses pemadaman busur api jenis gas $\mathrm{SF}_{6}$ [6].

1) Berdasarkan Tegangan Nominal

Berdasarkan besarnya tegangan operasi pada Pemutus Tenaga (PMT), PMT dapat dibedakan menjadi 4 jenis, yaitu antara lain:

- PMT tegangan rendah (Low Voltage), dengan range tegangan $0.1 \mathrm{~s} / \mathrm{d} 1 \mathrm{kV}$ (SPLN 1.1995 - 3.3).

- PMT tegangan menengah (Medium Voltage), dengan range tegangan $1 \mathrm{~s} / \mathrm{d}$ $35 \mathrm{kV}$ (SPLN 1.1995 - 3.4).

- PMT tegangan tinggi (High Voltage), dengan range tegangan $35 \mathrm{~s} / \mathrm{d} 245 \mathrm{kV}$ (SPLN $1.1995-3.5$ ).
- PMT tegangan extra tinggi (Extra High Voltage), dengan range tegangan $\geq 245$ kVAC (SPLN 1.1995 - 3.6).

2) Berdasarkan Jumlah Mekanik Penggerak PMT dapat dibedakan menjadi 2 jenis, berdasarkan jumlah dari mekanik penggerak tiap fasa kontak yang dimilikinya, yaitu:

- PMT Single Pole, memiliki mekanik penggerak di setiap pole fasanya dengan tujuan agar dapat melakukan operasi kerja reclose di salah satu fasanya. Jenis ini basanya digunakan pada bay penghantar.

- PMT Three Pole, hanya memiliki satu mekanik penggerak utama yang dikopel untuk menggerakkan ketiga kontak fasanya. Jenis ini umumnya digunakan pada bay trafo dan kopel serta PMT distribusi $20 \mathrm{kV}$.

\section{3) Berdasarkan Media Solusi}

Media isolasi pada PMT dapat berfungsi sekaligus sebagai media pemadam busur api yang timbul pada saat PMT bekerja membuka atau menutup. Berdasarkan media isolasi pemadam busur apinya, PMT dapat dibedakan menjadi 4 jenis, yaitu:

- PMT gas SF6, menggunakan gas $\mathrm{SF}_{6}$ sebagai media pemadam busur api ketika bekerja membuka kontaknya. Jenis ini biasanya dapat digunakan untuk memutus arus hingga $40 \mathrm{kA}$ pada sistem bertegangan sampai $765 \mathrm{kV}$.

- PMT minyak, menggunakan minyak sebagai media pemadam busur apinya. Jenis ini biasanya digunakan pada sistem bertegangan $6 \mathrm{kV}$ hingga $425 \mathrm{kV}$ yang dapat mengantarkan arus nominal dari 400 A sampai 1250 A dengan arus pemutusan simetris $12 \mathrm{kA}-50 \mathrm{kA}$.

- PMT media udara, menggunakan udara tegangan tinggi yang dihembuskan untuk memadamkan busur api. Jenis ini dapat digunakan untuk memutus arus hingga $40 \mathrm{kA}$ pada sistem bertegangan sampai $765 \mathrm{kV}$.

- PMT hampa udara, menggunakan ruangan hampa udara untuk menghilangkan busur api yang timbul. Jenis ini dapat digunakan untuk 
memutus sistem bertegangan hingga $38 \mathrm{kV}$.

- Proses pemadaman busur api jenis gas $\mathrm{SF}_{6}$.

PMT $\mathrm{SF}_{6}$ terbagi ke dalam dua jenis berdasarkan proses pemadaman busur api di ruang pemutusnya, yaitu:

- PMT jenis tekanan tunggal, gas $\mathrm{SF}_{6}$ ditekan melalui nozzle dengan tekanan gas $\pm 5 \mathrm{Kg} / \mathrm{cm}^{2}$ ke dalam sebuah tabung/cylinder yang menempel pada kontak saat terjadi pemutusan untuk melakukan pemadaman.

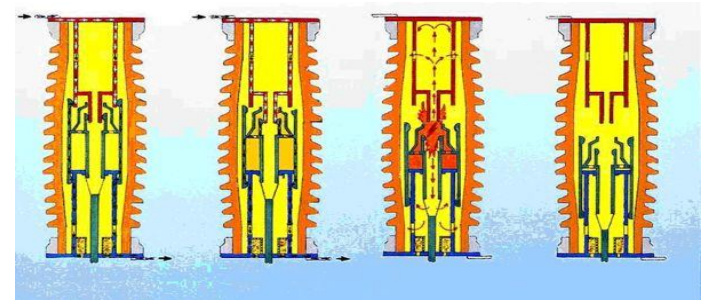

Gbr. 1 PMT SF6 Saat Proses Pemutusan Arus [6]

- PMT jenis tekanan ganda, PMT terisi gas $\mathrm{SF}_{6}$ dengan sistem tekanan tinggi kira-kira $12 \mathrm{Kg} / \mathrm{cm}^{2}$ dan sistem tekanan rendah kira-kira $2 \mathrm{Kg} / \mathrm{cm}^{2}$, pada waktu pemutusan busur api gas $\mathrm{SF}_{6}$ dari sistem tekanan tinggi dialirkan melalui nozzle ke sistem tekanan rendah. Gas pada sistem tekanan rendah kemudian dipompakan kembali ke sistem tekanan tinggi.

\section{Uji Kecepatan dan Keserempakan Kontak Pemutus Tenaga (PMT)}

Pemeliharaan PMT dilakukan dengan berbagai macam cara dengan periode waktu tertentu. Salah satu yang paling utama dari pengujian dan pemeliharaan yang dilakukan pada PMT adalah pengujian kecepatan dan keserempakan kontak pada tiap fasa PMT dengan alat ukur Breaker Analyzer [2]-[4], [8].

Pemeliharaan dan pengujian keserempakan kontak ini termasuk ke dalam jenis pemeliharaan "Shutdown Measurement/ Shutdown Function Check" atau yang biasa disebut dengan Inspeksi Level 3 (IL3), dimana pemeliharaan ini dilakukan dengan cara mengukur menggunakan alat ukur pada peralatan dalam keadaan tidak bertegangan
(Off Line) yang dilakukan secara rutin dengan periode waktu 2 tahunan [6].

Tujuan utama dari pengujian keserempakan PMT adalah untuk mengetahui kecepatan waktu kerja PMT di tiap fasanya (fasa R, S, dan T) serta mengetahui apakah waktu kerja dari kontak PMT tersebut serempak atau tidak ketika PMT beroperasi membuka ataupun menutup kontaknya [8]. Jadi, waktu kerja kontak dari Pemutus Tenaga (PMT) tersebut harus sesuai dengan nilai standar yang telah ditentukan dari pabrikan pembuat PMT tersebut.

Oleh karena itu waktu kerja yang dimiliki oleh ketiga fasanya tidak boleh terlalu cepat ataupun terlalu lambat dan wajib serempak ketika bekerja [6]. Berikut beberapa standar waktu kerja yang digunakan pada PMT 150 $\mathrm{kV}$ Mandirancan I dengan toleransi $\pm 10 \%$.

Tabel 1. Standar Acuan Waktu Kerja [6], [9] Standar Pabrikan GEC Alsthom $\quad$ Standar PLN

\begin{tabular}{|c|c|c|c|c|}
\hline $\begin{array}{c}\text { Open } \\
(\mathrm{ms})\end{array}$ & $\begin{array}{c}\text { Close } \\
(\mathrm{ms})\end{array}$ & $\begin{array}{c}\text { Operating } \\
\text { Sequence } \\
(\text { OC/OCO })\end{array}$ & $\begin{array}{c}\text { Max. } \\
\Delta t \\
(\mathrm{~ms})\end{array}$ & $\begin{array}{c}\text { Clearing } \\
\text { Time }(\mathrm{ms})\end{array}$ \\
\hline 28 & 150 & $300 \mathrm{~ms}$ & 10 & 120 \\
\hline \multicolumn{4}{|c|}{ Contact Bounce $(\mathrm{ms})$} & 10 \\
\hline \multicolumn{3}{|c|}{ Cycle } & 1 \\
\hline
\end{tabular}

Pengujian keserempakan kontak PMT ini dilakukan kepada semua jenis PMT, baik itu PMT Single Pole maupun PMT Three Pole. Dimana walaupun PMT Three Pole hanya memiliki satu mekanik penggerak yang di kopel untuk menggerakkan ketiga fasanya, hal ini tidak menutup kemungkinan PMT tersebut dapat memiliki perbedaan nilai waktu kerja pada kontaknya.

\section{Spesifikasi PMT 150 kV Mandirancan I}

PMT yang akan diuji dan dipelihara keserempakan kontaknya dengan Breaker Analyzer adalah PMT $150 \mathrm{kV}$ Single Pole di Bay (jalur) Mandirancan I di GI Sunyaragi. Media pemadam busur api yang digunakan pada PMT tersebut adalah gas $\mathrm{SF}_{6}$ (Sulfur Heksafluorida) dan menggunakan spring (pegas) sebagai mekanisme penggerak kontaknya. 


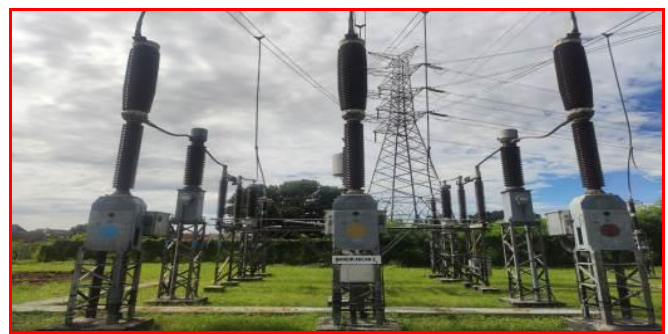

Gbr. 2 PMT 150 kV Single Pole Mandirancan I

Spesifikasi dari PMT yang akan diuji, yaitu PMT 150 kV Single Pole Bay Mandirancan I dapat dilihat pada gambar berikut:

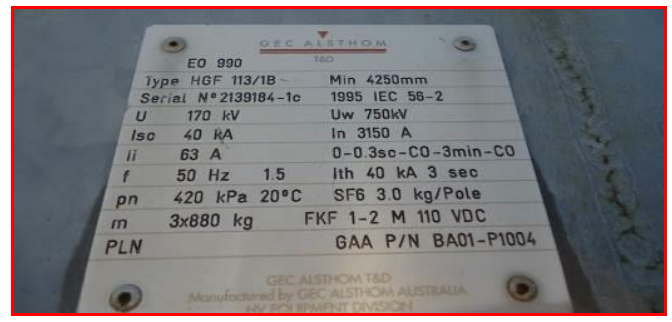

Gbr. 3 Spesifikasi PMT 150 kV Mandirancan I

Berdasarkan data yang diperoleh pada nameplate PMT Mandirancan I, diketahui karakteristik dan spesifikasi dari PMT yang akan diuji yaitu sebagai berikut.

Tabel 2. Sambungan Koneksi Kabel Initiate

\begin{tabular}{|c|c|c|}
\hline No & \multicolumn{2}{|c|}{ Spesifikasi } \\
\hline 1 & Merk PMT & GEC ALSHTOM \\
\hline 2 & Type & HGF 113/1B \\
\hline 3 & Serial Number & $2139184-1 \mathrm{a} / \mathrm{b} / \mathrm{c}$ \\
\hline 4 & Tahun Pembuatan & 1995 \\
\hline 5 & Tanggal Operasi & 1 Januari 1997 \\
\hline 6 & Buatan & Australia \\
\hline 7 & Rated Voltage (U) & $170 \mathrm{kV}$ \\
\hline 8 & $\begin{array}{l}\text { Rated Short Circuit } \\
\text { Breaking Current }\left(\mathrm{I}_{\mathrm{sc}}\right)\end{array}$ & $40 \mathrm{kA}$ \\
\hline 9 & $\begin{array}{l}\text { Rated Line Charging } \\
\text { Breaking Current }\left(\mathrm{I}_{\mathrm{i}}\right)\end{array}$ & $63 \mathrm{~A}$ \\
\hline 10 & Rated Frequency (f) & $50 \mathrm{~Hz}$ \\
\hline 11 & $\begin{array}{l}\text { Rated SF6 Gas } \\
\text { Pressure for } \\
\text { Interruption (pn) }\end{array}$ & $420 \mathrm{kPa} 20^{\circ} \mathrm{C}$ \\
\hline 12 & Mass (m) & $3 \times 880 \mathrm{~kg}$ \\
\hline 13 & $\begin{array}{l}\text { Rated Lightning Imp. } \\
\text { Withstand Voltage } \\
\left(\mathrm{U}_{\mathrm{w}}\right)\end{array}$ & $750 \mathrm{kV}$ \\
\hline 14 & $\begin{array}{l}\text { Rated Normal } \\
\text { Current }\left(I_{n}\right)\end{array}$ & $3150 \mathrm{~A}$ \\
\hline 15 & $\begin{array}{l}\text { Rated Operating } \\
\text { Sequence }\end{array}$ & $\begin{array}{l}\text { O-0.3s-CO-3min- } \\
\mathrm{CO}\end{array}$ \\
\hline 16 & $\begin{array}{l}\text { Rated Duration of } \\
\text { Short Circuit }\left(\mathrm{I}_{\mathrm{th}}\right)\end{array}$ & $40 \mathrm{kA} 3 \mathrm{sec}$ \\
\hline 17 & Mass of SF6 & $3.0 \mathrm{~kg} /$ Pole \\
\hline 18 & $\begin{array}{l}\text { Rated Supply Voltage } \\
\text { of Auxiliary Circuit }\end{array}$ & $110 \mathrm{VDC}$ \\
\hline
\end{tabular}

E. Breaker Analyzer

Dalam melakukan pengujian kecepatan waktu kerja kontak dan keserempakannya ini, alat ukur yang digunakan untuk mengukur kedua paramater tersebut adalah Digital Circuit Breaker Analyzer CT-6500 Series 2 [2]-[4], [8]. Breaker Analyzer ini merupakan alat ukur yang dibuat oleh pabrikan asal Ontario, California, Amerika Serikat yang bernama Vanguard Instruments Co., Inc [8]. Breaker Analyzer ini dapat mengukur kecepatan waktu kerja kontak dan keserempakan dari sebuah Circuit Breaker atau Pemutus Tenaga. Alat ini dapat mengukur dan menganalisis waktu kerja PMT ketika PMT Open (trip), Close (C), Open-Close (O-C Reclose), Close-Open ( $\mathrm{C}-$ $\mathrm{O})$, dan Open-Close-Open (O-C-O) [8].

Selain mengukur kecepatan dan keserempakan kontak PMT, alat ukur Breaker Analyzer ini juga akan mengukur beberapa paramater lainnya, diantaranya yaitu Insertion Resistor Contact Open and Close times, Contact Bounce Time, Resistor On Time, dan Contact Spread Times [8].

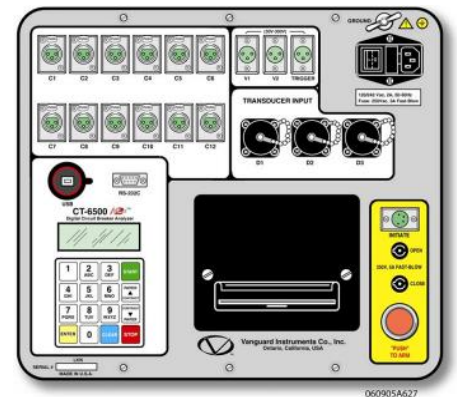

Gbr. 4 Digital Circuit Breaker Analyzer CT6500 Series $2[8]$

\section{METODOLOGI PENELITIAN}

\section{A. Diagram Alir Penelitian}

Dalam melakukan penelitian ini, terdapat beberapa metode dan tahapan penelitian yang dilakukan agar dapat menentukan kelayakan operasi dari sebuah PMT melalui sejumlah pengujian yang didasarkan pada keserempakan kontaknya. Adapun tahapan penelitian tersebut antara lain:

1) Identifikasi Masalah

Identifikasi masalah merupakan tahapan awal yang dilakukan dalam penelitian ini, 
pada tahapan ini dilakukan pencarian informasi mengenai riwayat kerja PMT 150 $\mathrm{kV}$ Mandirancan I melalui dokumen laporan teknik dan wawancara dengan Supervisor Jaringan dan Gardu Induk (JARGI) serta Supervisor Pemeliharaan Gardu Induk (HARGI) Sunyaragi mengenai sumber pokok permasalahan yang biasanya terjadi pada PMT yang sudah berumur dan alasan mengapa pentingnya PMT rutin dipelihara. Berdasarkan hasil observasi yang dilakukan, diketahui permasalahan yang biasanya terjadi pada PMT ini adalah tidak serempaknya waktu kerja yang dimiliki oleh tiap kontak antar fasanya ketika PMT tersebut bekerja membuka atau menutup kontaknya.

\section{2) Studi Literatur}

Pada tahapan ini aktifitas penelitian diutamakan untuk mencari bahan penelitian untuk dijadikan referensi penulisan dan penelitian terkait konsep sistem distribusi tenaga listrik pada sebuah Gardu Induk (GI) melalui beberapa sumber yang relevan dan terpercaya dari jurnal - jurnal ilmiah, artikel, serta buku pedoman pemeliharaan Gardu Induk PT. PLN (Persero), khususnya pada Circuit Breaker (CB) atau yang biasa disebut dengan Pemutus Tenaga (PMT) dan mengkaji permasalahan yang berkaitan dengan PMT di GI Sunyaragi, yaitu ketidak serempakannya kontak PMT Single Pole yang ada di bay (jalur) penghantar Mandirancan I $150 \mathrm{kV}$.

\section{3) Studi Lapangan}

Pada tahapan ini dilakukan pengamatan secara langsung ke lapangan, tepatnya di Gardu Induk Sunyaragi untuk melihat secara langsung bagaimana PMT $150 \quad \mathrm{kV}$ Mandirancan I bekerja ketika membuka ataupun menutup kontaknya pada saat dilakukan pengujian dan pemeliharaan rutin 2 tahunan pada PMT tersebut.

\section{4) Pengumpulan Data}

Pengumpulan data dilakukan ketika kegiatan pemeliharaan rutin 2 tahunan selesai dilakukan, data yang digunakan untuk melakukan evaluasi dan analisa merupakan data printout hasil pengujian yang dilakukan oleh alat ukur Breaker Analyzer yang akan menghitung kecepatan waktu kerja kontak PMT dari tiap kontak pada fasanya. Selain hasil pengujian terbaru yang diambil, laporan pengujian yang dilakukan pada tahun - tahun sebelumnya juga ikut digunakan sebagai bahan perbandingan penelitian keserempakan.

\section{5) Pengolahan Data}

Data yang diperoleh akan dilakukan validasi terlebih dahulu oleh Supervisor HARGI Sunyaragi untuk dilakukan verifikasi terkait hasil pengujian yang diperoleh untuk digunakan sebagai bahan penelitian. Jika dirasa data belum valid, maka kembali lagi ke dalam proses pengumpulan data dengan mencari data yang valid untuk pengujian.

Setelah data yang dikumpulkan sudah cukup dan valid dari segi informasinya maka data tersebut kemudian dikelompokkan berdasarkan tahun pengujiannya, kecepatan waktu kerja antar fasanya, perhitungan perbedaan (deviasi) waktu tertinggi antar fasa, lamanya waktu Contact Bounce, nilai besaran cycle ketika bekerja, beserta besarnya Initiator Current untuk digunakan sebagai bahan evaluasi dan analisis dari penelitian pengujian yang dilakukan.

\section{6) Analisa dan Evaluasi Data}

Data yang telah diolah akan dianalisa dan dievaluasi untuk menentukan kelayakan operasi kerja dari PMT $150 \mathrm{kV}$ Mandirancan I. Dimana dalam tahapan ini, data yang diperoleh akan dievaluasi dengan cara membandingkan hasil pengujian yang diperoleh dengan data hasil pengujian terdahulu menggunakan prinsip trend 3 kali pemeliharaan pada bay (jalur) Mandirancan I tersebut, yang berarti data hasil pengujian yang dilakukan pada tahun 2020 akan dibandingkan dengan hasil pengujian yang dilakukan pada tahun 2018, 2016, dan 2014. Selain menggunakan cara tersebut, hasil pengujiannya juga akan dianalisis untuk disesuaikan dengan Standar PLN (SPLN) itu sendiri serta nilai standar yang berasal dari pabrikan PMT tersebut.

7) Rekomendasi dan Solusi

Pada tahapan ini dilakukan beberapa tindakan atau pemeliharaan lebih lanjut berdasarkan dari parameter waktu kerja 
kontak yang telah dianalisa, sesuai dengan rekomendasi dari PLN serta indikasi temuan anomali penyebab permasalahan pada PMT tersebut.

8) Kesimpulan dan Saran

Tahapan terakhir dari penelitian ini yaitu penarikan sebuah kesimpulan dan beberapa saran untuk permasalahan yang terjadi mengenai masalah keserempakan kontak PMT yang terjadi di PMT $150 \quad \mathrm{kV}$ Mandirancan I. Keseluruhan tahapan tahapan penelitian ini jika digambarkan ke dalam bentuk diagram alir penelitian, maka akan menghasilkan diagram seperti pada gambar berikut.

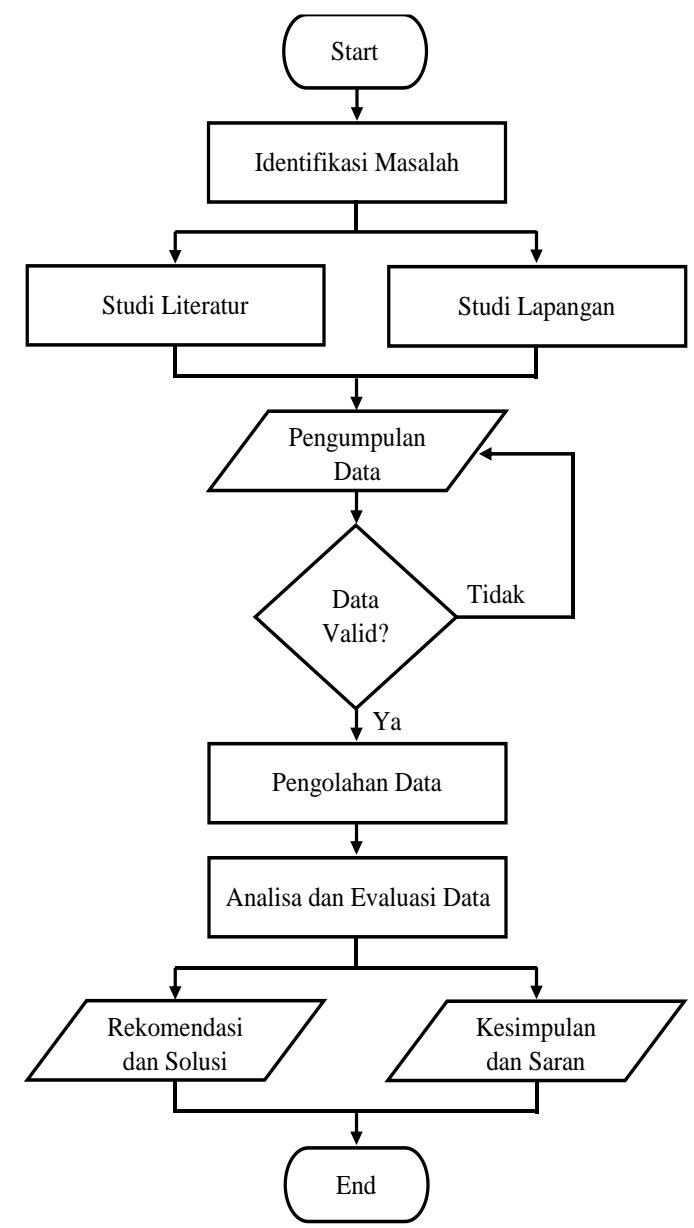

Gbr. 5 Diagram Alir Penelitian

\section{B. Rangkaian Pengujian PMT Dengan} Breaker Analyzer

Dalam melakukan pengukuran dan pengujian kecepatan waktu kerja dan keserempakan kontak pada PMT menggunakan Breaker Analyzer, kita harus memahami terlebih dahulu skematik rangkaian pengujian yang menghubungkan tiap - tiap komponen pada Breaker Analyzer dengan PMT. Jika pada saat merangkai rangkaian pengujian terdapat sebuah kesalahan koneksi atau pemasangan yang kurang baik, maka Breaker Analyzer tidak akan dapat menghitung waktu kerja dari PMT tersebut dengan benar. Agar Breaker Analyzer terhubung dengan baik, berikut skematik rangkaian pengujian yang harus diikuti ketika akan melakukan pengujian dengan Breaker Analyzer CT-6500 Series 2.

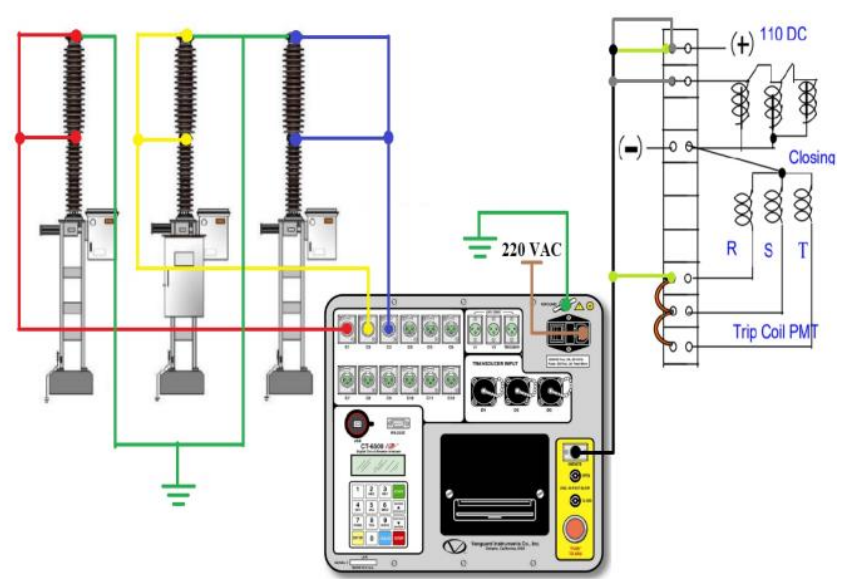

Gbr. 6 Skematik Rangkaian Pengujian Waktu dan Keserempakan PMT [2]-[4], [8]

Jika dilihat dari skematik rangkaian pengujian, untuk melakukan pengukuran dan pengujian pada sebuah Pemutus Tenaga (PMT) kita hanya perlu menghubungkan 3 buah Contact Input pada Breaker Analyzer (C1, C2, C3). Ketiga buah Contact Input tersebut dihubungkan pada masing - masing pole pada PMT dengan menggunakan kabel konektor kontak pole PMT agar Breaker Analyzer dapat melakukan pengukuran waktu kerja kontaknya melalui perhitungan dan pengukuran kecepatan arus yang mengalir dari PMT menuju alat ukur melewati konektor pole atas dan bawah PMT.

Dimana nantinya Contact Input $\mathrm{C} 1$ akan dihubungkan ke pole atas dan bawah pada PMT Fasa R, lalu Contact Input C2 pada pole atas dan bawah PMT Fasa $\mathrm{S}$, dan Contact Input $\mathrm{C} 3$ dihubungkan pada pole atas dan bawah PMT Fasa T. Bentuk fisik kabel konektor pole PMT tersebut dapat dilihat seperti pada gambar berikut. 


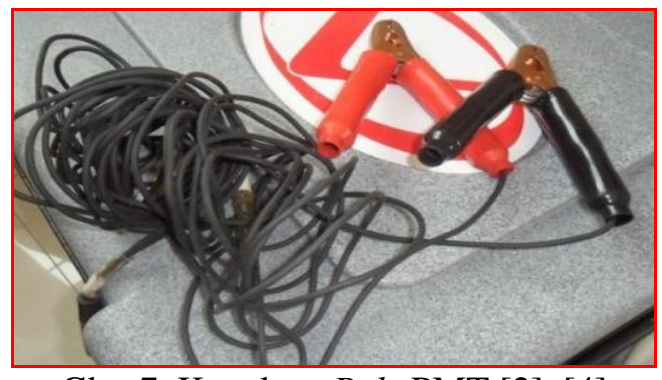

Gbr. 7 Konektor Pole PMT [2], [4]

Berikutnya hubungkan kontak Initiate pada alat ukur dengan Triping Coil (TC), Closing Coil (CC), dan sumber tegangan positif 110 VDC pada box kontrol PMT dengan kabel konektor Initiate untuk menghidupkan sehingga Breaker Analyzer dapat melakukan pengaturan buka tutupnya kontak PMT di tiap fasanya.

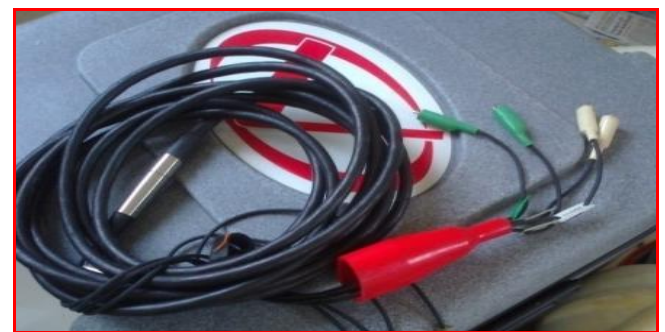

Gbr. 8 Kabel Konektor Initiate [2], [4]

Konektor ini terdiri dari 4 pin konektor dengan 2 warna yang berbeda, masing masing warna tersebut memiliki fungsi tersendiri. Satu buah kabel konektor pin berwarna hijau adalah kabel konektor Initiate yang menghubungkan Breaker Analyzer dengan terminal kontaktor Triping Coil (TC), sedangkan untuk 1 buah kabel konektor pin berwarna putih keabuan menghubungkan Breaker Analyzer dengan terminal kontaktor Closing Coil (CC). Sisa 2 buah konektor pin lainnya yang berwarna hijau dan putih, keduanya saling terhubung dengan sumber tegangan +110VDC. Untuk lebih jelasnya, berikut tabel konfigurasi konektor initiate yang digunakan selama pengujian dilakukan.

Tabel 3. Sambungan Koneksi Kabel Initiate

\begin{tabular}{|c|l|l|l|}
\hline No & \multicolumn{1}{|c|}{$\begin{array}{c}\text { Warna } \\
\text { Kabel }\end{array}$} & \multicolumn{1}{|c|}{ Sambungan } & $\begin{array}{l}\text { No. } \\
\text { Kontak }\end{array}$ \\
\hline 1 & Hijau-1 & $\begin{array}{l}\text { Open (Triping } \\
\text { Coil) TC }\end{array}$ & $\begin{array}{l}13 \mathrm{~A}, \\
13 \mathrm{~B}, \\
13 \mathrm{C}\end{array}$ \\
\hline 2 & Hijau-2 & +110 VDC & 19 \\
\hline 3 & Keabuan-1 & $\begin{array}{l}\text { Closing Coil } \\
\text { (CC) PMT }\end{array}$ & 16 \\
\hline 4 & Keabuan-2 & +110 VDC & 19 \\
\hline
\end{tabular}

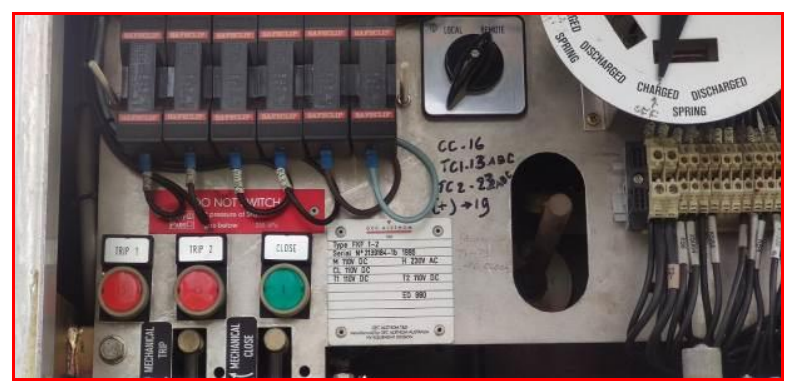

Gbr. 9 Informasi Sambungan Kabel Initiate di Dalam Box PMT

C. Diagram Alir Pengujian Keserempakan Dengan Breaker Analyzer

Dalam pemeliharaan PMT Mandirancan I, khususnya ketika dilakukan pengujian waktu kerja dan keserempakan kontak PMT dengan Breaker Analyzer terdapat berbagai macam prosedur dan tahapan yang harus dilakukan sebelum memulai pengujian, ketika sedang menguji dan setelah selesai dilakukannya pengujian. Berikut beberapa prosedur yang harus diikuti oleh para personil di lapangan tempat pemeliharaan berlangsung agar pengujian dapat berjalan dengan baik dan menghasilkan nilai hasil pengujian yang akurat.

- Personil Jaringan dan Gardu Induk (Jargi) melakukan manuver pembebasan tegangan sesuai dengan prosedur pada bay Mandirancan I $150 \mathrm{kV}$. Dimana setelah tegangan berhasil dibebaskan, lakukan persiapan pengujian dengan memakai peralatan K3 sebelumnya dan mulai merangkai rangkaian pengujian sesuai skematik dengan memasang kabel grounding lokal PMT dan alat ukur, memasang kabel Initiate dan Contact Input serta menghubungkan kabel power 220 VAC pada Breaker Analyzer.

- Input data teknis PMT yang akan diuji melalui keypad bawaan Breaker Analyzer dan atur pengujian yang akan dilakukan dengan memilih menu yang terdapat pada LCD Display Breaker Analyzer.

- Uji PMT dan tunggu printout laporan hasil pengujian dari thermal printer bawaan Breaker Analyzer.

- Periksa apakah hasil yang diperoleh sesuai dengan standar pabrikan maupun SPLN dan rekomendasi yang ada.

- Jika hasil tidak sesuai standar, maka lakukan beberapa langkah pengujian dan 
pemeriksaan sesuai dengan rekomendasi dari PT. PLN (Persero). Lakukan pengujian kembali untuk memeriksa apakah hasil pengujian sudah sesuai dengan standar atau tidak.

- Jika hasil pengujian sudah sesuai dengan standar, maka pengujian telah berhasil dilakukan dengan baik. Setelah selesai melakukan pengujian lepaskan kabel kabel rangkaian pengujian yang terhubung pada PMT dan rapikan kembali peralatan - peralatan yang digunakan selama melakukan pemeliharaan pengujian kecepatan waktu kerja dan keserempakan kontak PMT.

Keseluruhan instruksi kerja dan tahapan dari pengujian keserempakan menggunakan alat ukur Breaker Analyzer ini dapat diringkas dan digambarkan melalui diagram alir pengujian seperti yang dapat dilihat pada gambar berikut.

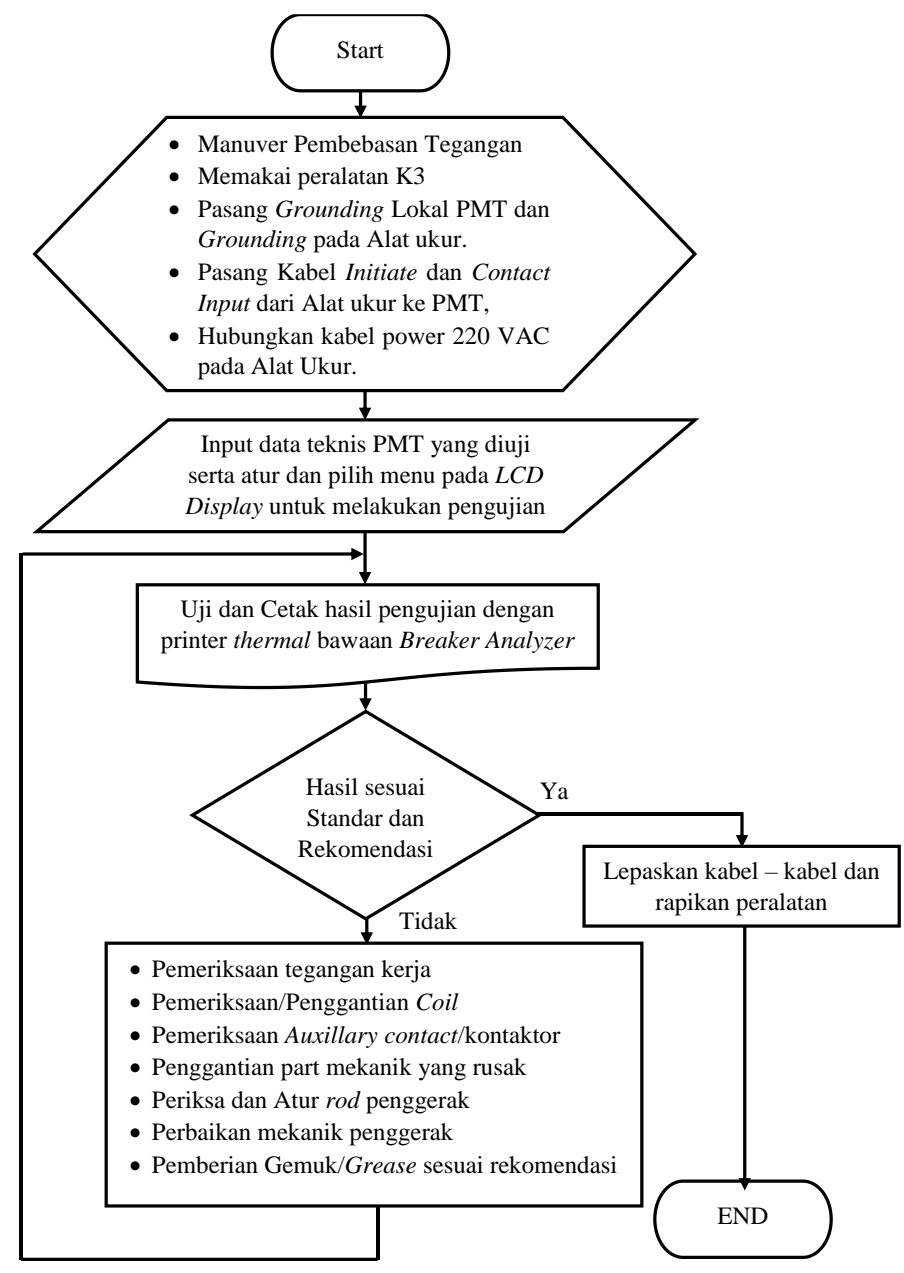

Gbr. 10 Flowchart Pengujian Kecepatan dan Keserempakan Kerja PMT

\section{HASIL DAN PEMBAHASAN}

Dalam pemeliharaan rutin Shutdown Measurement 2 tahunan yang dilakukan pada bay (jalur) penghantar Mandirancan I, khususnya pada bagian pemeliharaan Pemutus Tenaga (PMT) $150 \mathrm{kV}$ Single Pole Mandirancan I. Pengujian kecepatan waktu kerja dan keserempakan kontak PMT dengan menggunakan alat ukur Digital Circuit Breaker Analyzer CT-6500 Series 2 dilakukan sebanyak 4 kali percobaan. Adapun pengujian tersebut antara lain:

- Pengujian kontak terbuka (Open/Trip).

- Pengujian kontak tertutup (Close).

- Pengujian kontak Reclose (Open Close).

- Pengujian kontak Open - Close - Open $(\mathrm{O}-\mathrm{C}-\mathrm{O})$.

\section{A. Pengujian Waktu Kontak Terbuka (Open/Trip)}

Pengujian ini dilakukan untuk mengetahui seberapa cepat PMT bekerja dalam membuka kontaknya. Pengukuran kecepatan waktu kerja kontak terbuka diukur dengan menggunakan Breaker Analyzer, dimana hasil yang diperoleh didapat dari perhitungan waktu kerja PMT ketika tombol "Push to Arm" pada Breaker Analyzer ditekan sampai dengan Moving Contact di dalam Interrupter Chamber PMT bergerak terlepas dari Fix Contact PMT tersebut sehingga kontak PMT akan terbuka dan terlepas dari beban. Berikut hasil pengujian yang diperoleh ketika melakukan pengujian waktu kontak PMT terbuka (Open/Triping).

Jika dilihat dari hasil printout pengujian diatas, berikut hasil rangkuman pengujian yang disajikan dalam bentuk tabel. 


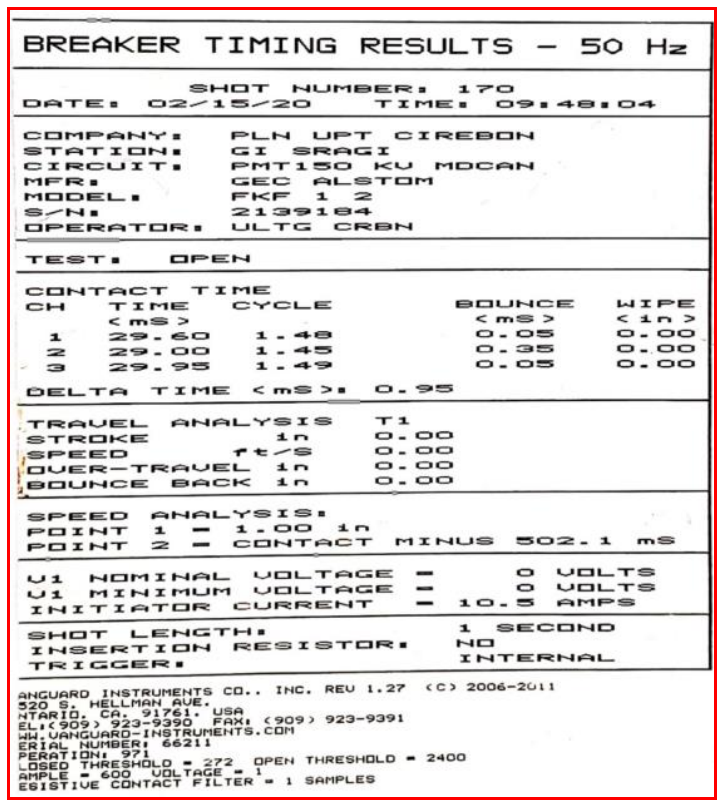

Gbr. 11 Printout Hasil Pengujian Waktu Open PMT $150 \mathrm{kV}$ Mandirancan I

Tabel 4. Hasil Pengujian Waktu Open PMT $150 \mathrm{kV}$ Mandirancan I

\begin{tabular}{|c|c|c|c|c|c|} 
Fasa & $\begin{array}{c}\text { Contact } \\
\text { Time } \\
(\mathrm{ms})\end{array}$ & $\begin{array}{c}\text { Contact } \\
\text { Bounce } \\
(\mathrm{ms})\end{array}$ & Cycle & $\begin{array}{c}\Delta \mathrm{t} \\
(\mathrm{ms})\end{array}$ & $\begin{array}{c}\text { Initiator } \\
\text { Current } \\
(\mathrm{A})\end{array}$ \\
\hline $\mathrm{R}$ & 29.60 & 0.05 & 1.48 & & \multirow{2}{*}{0.95} \\
\cline { 1 - 4 } $\mathrm{S}$ & 29.00 & 0.35 & 1.45 & 0.5 \\
\cline { 1 - 4 } $\mathrm{T}$ & 29.95 & 0.05 & 1.49 & & \\
\hline
\end{tabular}

Selain dapat mengetahui waktu kerja keseluruhan ketika PMT beroperasi, pengujian dengan Breaker Analyzer ini juga dapat mengetahui lama waktu Contact Bounce dan Cycle pada PMT tersebut. Countact Bounce disini adalah nilai parameter waktu yang terjadi ketika Moving Contact dan Fix Contact pada Interrupter Chamber PMT menutup kontaknya, proses penutupan kontak PMT terjadi ketika Moving Contact dan Fix Contact terhubung satu sama lain, dimana dalam proses penghubungan kedua kontak ini terjadi karena gaya dorong oleh mekanik penggerak PMT pada Moving Contact sehingga Moving Contact akan bergerak menuju Fix Contact dalam kecepatan yang cukup tinggi.

Nilai waktu Contact Bounce ini didapatkan ketika Moving Contact dan Fix Contact saling bertabrakan ketika proses penutupan yang dapat menimbulkan bouncing (kontak memantul) sebelum kedua kontak tersebut benar - benar terhubung dengan stabil satu sama lainnya. Jadi nilai parameter waktu Contact Bounce ini hanya dapat terbaca ketika PMT sedang menutup kontaknya. Dimana pengaruh dari waktu Contact Bounce yang tinggi ini dapat menyebabkan busur api yang tercipta akibat kedua kontak yang saling bertabrakan akan semakin besar yang dikhawatirkan media pemadam dan isolasi pada PMT tidak cukup kuat untuk menahan dan memadamkan busur api tersebut. Hal ini juga dapat menciptakan lonjakan tegangan yang cukup tinggi sebelum kontak dapat terhubung dengan seutuhnya.

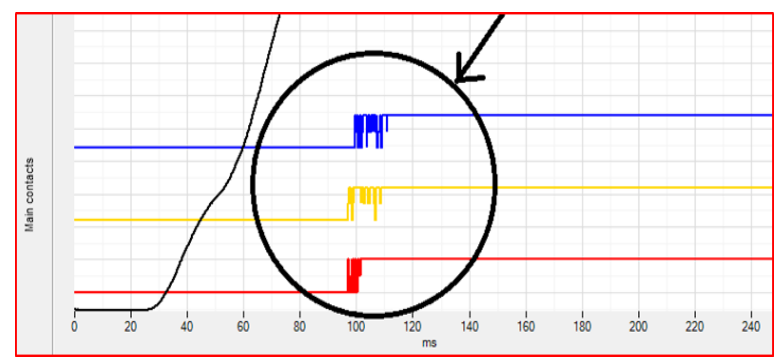

Gbr. 12 Ilustrasi Contact Bounce Pada Diagram Pewaktu

Contact Bounce Time pada saat pengujian waktu buka (Open) pada fasa $\mathrm{R}$ didapatkan sebesar $0.05 \mathrm{~ms}$, pada fasa $\mathrm{S}$ adalah $0.35 \mathrm{~ms}$, dan pada fasa T yaitu $0.05 \mathrm{~ms}$. Dimana jika dilihat, nilai waktu yang dihasilkan dan terbaca oleh alat ukur sangat kecil sehingga hal ini dapat diartikan bahwa kejadian Contact Bounce itu tidak terjadi saat PMT membuka kontaknya.

Nilai Cycle pada hasil pengujian Breaker Analyzer merupakan cycle (siklus gelombang) ketika PMT tersebut bekerja membuka atau menutup ketiga fasa kontaknya hingga beban terhubung atau terputus sepenuhnya. Nilai Cycle ini tidak diperbolehkan memiliki perbedaan (deviasi) lebih dari 1 Cycle yang dihitung dari selisih nilai antara Cycle tertingi dan terendah dari ketiga fasa tersebut. Dalam melakukan pengujian, Breaker Analyzer mengggunakan prinsip injeksi arus dan besarnya arus yang diinjeksikan pada Coil PMT melalui kabel konektor Initiate pada Breaker Analyzer adalah 10.5 A.

Jika hasil pengujian yang diperoleh dibandingkan dengan trend 3 kali pemeliharaan pada tahun - tahun sebelumnya, didapat perbandingan nilai waktu kerja seperti berikut. 


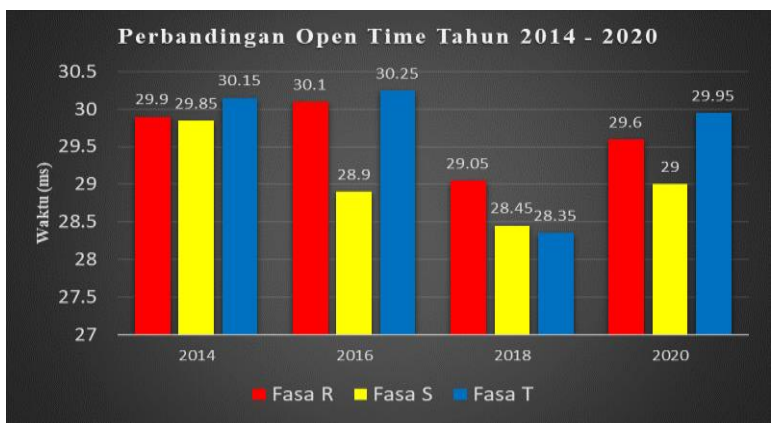

Gbr. 13 Grafik Perbandingan Waktu Kerja PMT Membuka Kontak

Jika dilihat dari semua hasil pengujian diatas, untuk waktu kerja dan keserempakan ketika PMT $150 \mathrm{kV}$ Mandirancan I membuka kontaknya, waktunya masih cukup baik dan sesuai dengan trend 3 kali pemeliharaan 2 tahunan serta standar dari pabrikan pembuat PMT tersebut dan juga dari SPLN itu sendiri

\section{B. Pengujian Waktu Kontak Tertutup (Close)}

Pengujian ini dilakukan untuk mengetahui waktu kerja dan keserempakan PMT ketika menutup ketiga fasa kontaknya. Dimana hasil pengujian waktu kerjanya diperoleh dari perhitungan Breaker Analyzer ketika tombol "Push to Arm" ditekan sampai dengan Moving Contact di dalam Interrupter Chamber PMT bergerak dan terhubung dengan stabil pada Fix Contact dari PMT tersebut. Berdasarkan standar SPLN, batas maksimal waktu kerja PMT untuk PMT 150 $\mathrm{kV}$ Mandirancan I ketika melakukan proses penutupan kontaknya adalah $150 \mathrm{~ms}$. Berikut hasil printout pengujian waktu tutup (Close) yang diperoleh saat pemeliharaan PMT 150 $\mathrm{kV}$ Mandirancan I.

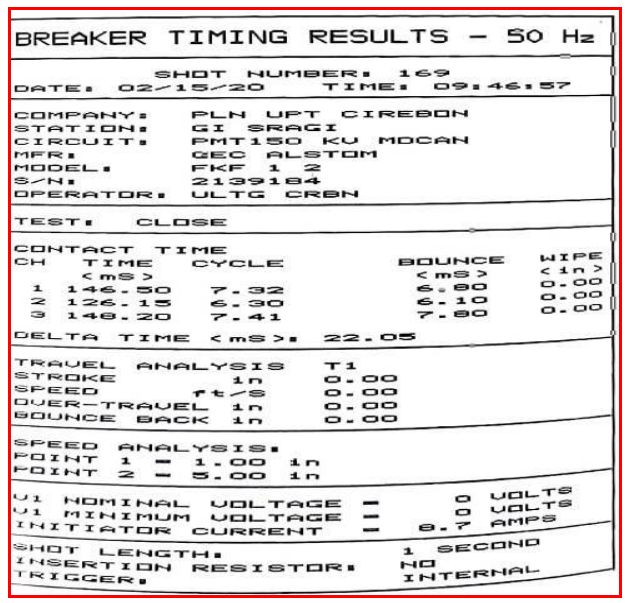

Gbr. 14 Printout Hasil Pengujian Waktu Close PMT 150 kV Mandirancan I
Seperti yang dapat dilihat dari percobaan pengujian waktu tutup kontak PMT yang dilakukan, didapat beberapa parameter pengujian PMT yang dapat dilihat pada tabel berikut ini.

Tabel 5. Hasil Pengujian Waktu Close PMT 150 $\mathrm{kV}$ Mandirancan I

\begin{tabular}{|c|c|c|c|c|c|} 
Fasa & $\begin{array}{c}\text { Contact } \\
\text { Time } \\
(\mathrm{ms})\end{array}$ & $\begin{array}{c}\text { Contact } \\
\text { Bounce } \\
(\mathrm{ms})\end{array}$ & Cycle & $\begin{array}{c}\Delta \mathrm{t} \\
(\mathrm{ms})\end{array}$ & $\begin{array}{c}\text { Initiator } \\
\text { Current } \\
(\mathrm{A})\end{array}$ \\
\hline $\mathrm{R}$ & 146.50 & 6.80 & 7.32 & & \\
$\mathrm{yyyynn} \mathrm{S}$ & 126.15 & 6.10 & 6.30 & 22.05 & 8.7 \\
\cline { 1 - 4 } $\mathrm{T}$ & 148.20 & 7.80 & 7.41 & & \\
\hline
\end{tabular}

Berdasarkan hasil pengujian yang diperoleh, dapat diketahui bahwa hasil pengujian kecepatan waktu kerja kontak ketika menutup (close) kontak pada fasa R, S, dan $\mathrm{T}$ berturut - turut adalah $146.50 \mathrm{~ms}$, $126.15 \mathrm{~ms}$, dan $148.20 \mathrm{~ms}$. Hasil waktu kerja tersebut jika dilihat pada standar SPLN untuk PMT $150 \mathrm{kV}$ Mandirancan I maka, waktu kerja tersebut masih dalam batas normal dan tidak melebihi besarnya waktu kerja yang telah ditentukan oleh pabrikan ataupun PLN itu sendiri.

Namun, untuk perbedaan (deviasi) waktu terbesar yang dimiliki oleh tiap kontak tersebut ketika menutup adalah $22.05 \mathrm{~ms}$, dimana nilai ini melebihi dari deviasi waktu terbesar yang diijinkan oleh pabrikan PMT $150 \mathrm{kV}$ Mandirancan I tersebut, yaitu tidak lebih dari $10 \mathrm{~ms}$. Kontak yang bekerja terlalu cepat, maupun terlalu lambat dapat mempengaruhi besarnya nilai cycle pada tiap kontak PMT tersebut ketika bekerja sehingga tidak baik pada keberlangsungan penyaluran tenaga listrik yang mengalir melalui PMT tersebut. Dimana pada kasus di PMT $150 \mathrm{kV}$ Mandirancan I ini, perbedaan nilai cycle tertinggi terdapat antara fasa $\mathrm{S}$ dengan fasa $\mathrm{T}$ yang berbeda 1.11 cycle.

Perbedaan nilai cycle yang dimiliki oleh PMT tersebut telah melewati perbedaan nilai cycle yang diijinkan pada sistem penyaluran tenaga listrik, yaitu 1 cycle. Maka dari itu perbedaan nilai waktu kerja ketika menutup kontak pada PMT ini harus segera diperbaiki sesuai dengan rekomendasi dari PLN, berdasarkan permasalahan yang menyebabkan temuan pada anomali waktu tersebut. 
Untuk waktu kontak memantul (Contact Bounce) pada ketiga fasanya, yaitu fasa $\mathrm{R}$ selama $6.80 \mathrm{~ms}$, pada fasa $\mathrm{S}$ selama $6.10 \mathrm{~ms}$, dan pada fasa $\mathrm{T}$ selama $7.80 \mathrm{~ms}$. Dimana besarnya nilai waktu Contact Bounce yang disarankan untuk PMT ini adalah tidak lebih dari $10 \mathrm{~ms}$, oleh karena itu, hal ini menunjukkan bahwa besarnya Contact Bounce Time pada PMT ini telah sesuai dengan rekomendasi waktu yang diberikan. Besarnya injeksi arus yang diberikan oleh alat ukur pada Closing Coil PMT untuk melakukan melakukan pengujian waktu kerja ketika PMT menutup kontaknya adalah sebesar 8.7 Ampere.

Jika data hasil pengujian tersebut dibandingkan dengan trend 3 kali pemeliharan 2 tahunan, dari tahun 2014 2018, maka akan menghasilkan bentuk grafik seperti pada gambar berikut.

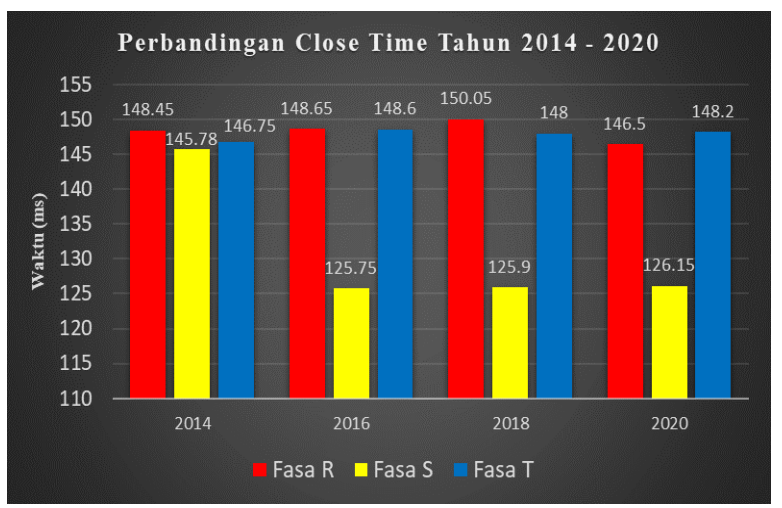

Gbr. 15 Grafik Perbandingan Waktu Kerja PMT Menutup Kontak

Jika dilihat pada grafik diatas, dapat diketahui ternyata anomali perbedaan deviasi waktu yang besar ini telah terjadi dari 4 tahun sebelumnya, yaitu pada tahun 2016. Dimana pada tahun 2014 besarnya deviasi waktu di tiap fasanya masih normal, dan baru terjadi pada tahun 2016. Hal ini menyebabkan nilai waktu kerja pada fasa $S$ menjadi lebih cepat \pm 23 ms dari kedua fasa lainnya sehingga menyebabkan deviasi waktu yang dimiliki oleh PMT tersebut melebihi batas standar dari pabrikan PMT GEC ALSHTOM. Dalam kasus ini sebaiknya PMT tersebut harus segera dilakukan perbaikan ataupun penggantian unit PMT dengan yang baru agar tetap dapat menjaga kualitas dan kontinuitas dalam proses penyaluran tenaga listrik.

\section{Pengujian kontak Reclose (Open-Close)}

Pada pengujian ini dilakukan pengujian untuk mengetahui kecepatan waktu kerja dan keserempakan kontak PMT ketika PMT bekerja untuk reclose (buka tutup) kontak pada tiap fasanya. Lamanya waktu kerja kontak PMT reclose ini diperoleh dari perhitungan saat PMT dalam kondisi close dan tombol "Push to Arm" pada alat ukur ditekan sehingga menyebabkan kontak PMT terbuka dengan cepat dan kemudian sesaat setelah kontak PMT terbuka akan diikuti dengan proses penutupan kembali kontak PMT tersebut hingga hingga kondisi Moving Contact dan Fix Contact pada PMT benar benar terhubung satu sama lainnya. Berikut hasil pengujian yang diperoleh.

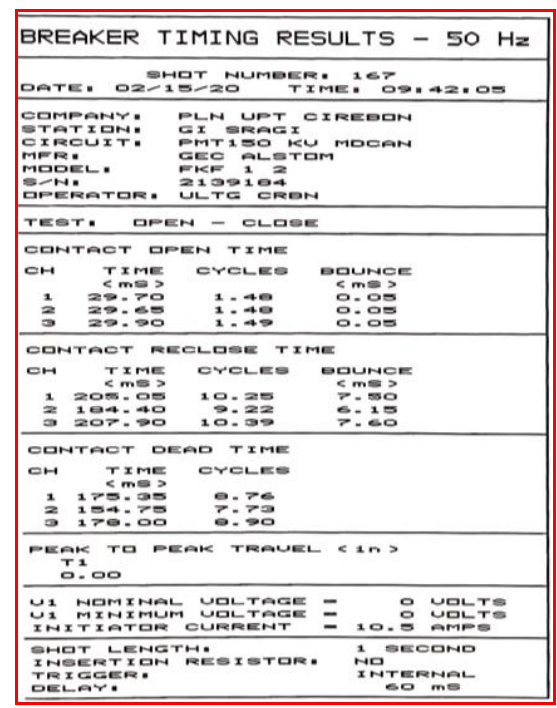

Gbr. 16 Printout Hasil Pengujian Waktu Reclose PMT $150 \mathrm{kV}$ Mandirancan I

Seperti yang dapat dilihat pada printout hasil pengujian diatas, terdapat beberapa poin utama seperti yang dilihat pada tabel berikut.

Tabel 6. Hasil Pengujian Waktu Reclose PMT $150 \mathrm{kV}$ Mandirancan I

\begin{tabular}{|c|c|c|c|c|c|}
\hline Fasa & $\begin{array}{c}\text { Contact } \\
\text { Reclose } \\
\text { Time } \\
(\mathrm{ms})\end{array}$ & $\begin{array}{c}\text { Contact } \\
\text { Bounce } \\
\text { (ms) }\end{array}$ & $\begin{array}{c}\text { Contact } \\
\text { Dead } \\
\text { Time } \\
(\mathrm{ms})\end{array}$ & Cycle & $\begin{array}{c}\Delta \mathrm{t} \\
(\mathrm{ms})\end{array}$ \\
\hline $\mathrm{R}$ & 205.05 & 7.50 & 175.35 & 10.25 & \\
\hline $\mathrm{S}$ & 184.40 & 6.15 & 154.75 & 9.22 & 23.50 \\
\hline $\mathrm{T}$ & 207.90 & 7.60 & 178.00 & 10.39 & \\
\hline \multicolumn{4}{|c|}{ Initiator Current (A) } & \multicolumn{2}{|c|}{10.5} \\
\hline
\end{tabular}


Berdasarkan hasil pengujian yang diperoleh dengan masukan Initiator Current sebesar 10.5A, diketahui lamanya waktu kerja PMT ketika reclose pada fasa $\mathrm{R}$ yaitu $205.05 \mathrm{~ms}$, pada fasa $\mathrm{S}$ selama $184.40 \mathrm{~ms}$, dan yang terakhir pada fasa $\mathrm{T}$ yaitu selama 207.90 ms. Jika mengacu pada standar yang telah ditetapkan dari "Rated Operating Sequence" yang terdapat pada spesifikasi teknis PMT $150 \mathrm{kV}$ Mandirancan I, lamanya waktu kerja kontak PMT pada masing masing fasanya untuk melakukan operasi kerja reclose masih berada di bawah nilai waktu standar yang diijinkan, yaitu $\leq 300 \mathrm{~ms}$.

Seperti yang dapat dilihat dari deviasi jumlah cycle terbesar yang terjadi pada pengujian waktu kerja kontak reclose ini adalah 1.17 cycle, yang mana jumlah ini telah melebihi nilai standar yang ditentukan, yaitu 1 cycle. Untuk lamanya waktu Contact Bounce yang terjadi pada masing - masing kontak pada PMT Mandirancan I secara berturut - turut adalah $175.35 \mathrm{~ms}$ untuk fasa $\mathrm{R}, 154.75 \mathrm{~ms}$ untuk fasa $\mathrm{S}$, dan $7.60 \mathrm{~ms}$ untuk fasa $\mathrm{T}$.

Selain beberapa parameter yang telah disebutkan sebelumnya, terdapat paramater nilai baru yang bernama Contact Dead Time. Dimana maksud dari Contact Dead Time ini adalah waktu tunda (jeda) yang dibutuhkan oleh PMT sesaat setelah PMT melakukan operasi kerja untuk membuka kontaknya dengan sangat cepat hingga media pemadam dan isolasi pada PMT dapat memadamkan busur api yang timbul akibat kontak yang terbuka, sebelum PMT dapat kembali melakukan proses penutupan kontaknya kembali. Pada pengujian ini didapati lamanya waktu Contact Dead Time pada tiap kontaknya yaitu, pada fasa $\mathrm{R}$ selama 175.35 $\mathrm{ms}$, fasa S $154.75 \mathrm{~ms}$, dan pada fasa $\mathrm{T}$ selama $178.00 \mathrm{~ms}$.

Jika dilakukan perbandingan data hasil pengujian yang diperoleh dengan trend 3 kali pemeliharaan 2 tahunan pada tahun 2014 2018 sebelumnya, didapati grafik hasil perbandingan waktu kerja PMT pada saat reclose yang nampak seperti pada gambar grafik berikut.

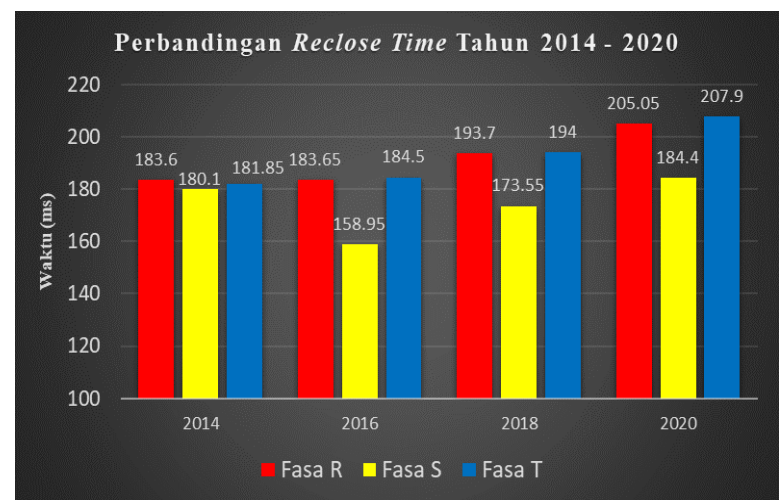

Gbr. 17 Grafik Perbandingan Waktu Kerja PMT Ketika Reclose Kontak

Jika dilihat pada grafik diatas, terlihat bahwa pada tahun 2014 waktu kerja reclose pada PMT Mandirancan I dapat dikatakan masih dalam kondisi yang baik, karena pada saat itu waktu kerja kontak fasa S ketika menutup kontaknya masih dalam kondisi yang normal dan baru mulai dari tahun 2016 terdapat perbedaan waktu kerja reclose yang besar karena fasa $\mathrm{S}$ bekerja lebih cepat daripada kedua fasa lainnya.

\section{Pengujian kontak Open - Close - Open $(\mathrm{O}-\mathrm{C}-\mathrm{O})$}

Pada pengujian ini dilakukan percobaan pengujian untuk mengetahui waktu kerja dan keserempakan kontak PMT ketika bekerja untuk reclose kontaknya yang kemudian diikuti dengan pembukaan kembali kontaknya. Jadi, dalam pengujian ini kontak PMT akan bekerja sebanyak 3 kali, yaitu pada saat posisi awal pengujian, kontak PMT akan bekerja membuka kontaknya lalu setelah beberapa saat kontak PMT akan menutup kembali, pada saat kontak PMT tersebut telah tertutup dan terhubung dengan baik, kemudian kontak PMT tersebut akan kembali bekerja untuk kembali membuka kembali kontaknya tersebut dengan cepat. Berikut printout hasil pengujian dari waktu OCO yang diperoleh saat pemeliharaan berlangsung. 


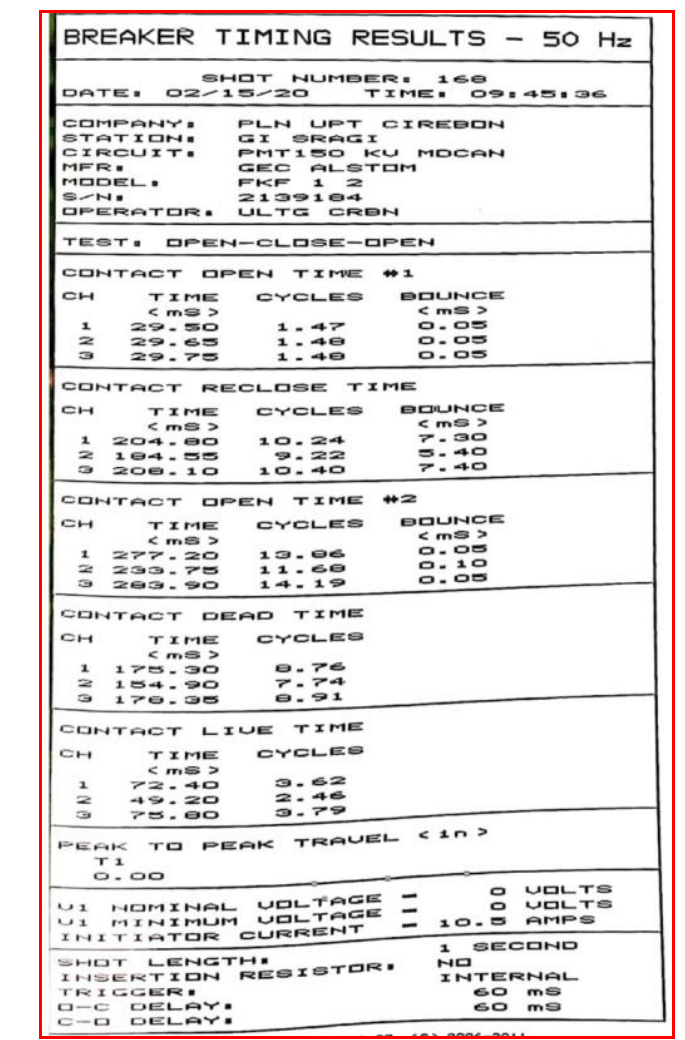

Gbr. 18 Printout Hasil Pengujian Waktu OCO PMT 150 kV Mandirancan I

Jika dilihat dari printout hasil pengujian diatas, berikut perolehan nilai waktu kerja PMT yang direpresentasikan ke dalam bentuk tabel seperti berikut.

Tabel 7. Hasil Pengujian Waktu OCO PMT 150 $\mathrm{kV}$ Mandirancan I

\begin{tabular}{|c|c|c|c|c|c|}
\multirow{2}{*}{ Fasa } & $\begin{array}{c}\text { Contact } \\
\text { OCO } \\
\text { Time } \\
(\mathrm{ms})\end{array}$ & $\begin{array}{c}\text { Contact } \\
\text { Dead } \\
\text { Time } \\
(\mathrm{ms})\end{array}$ & $\begin{array}{c}\text { Contact } \\
\text { Live } \\
\text { Time } \\
(\mathrm{ms})\end{array}$ & Cycle & $\begin{array}{c}\Delta \mathrm{t} \\
(\mathrm{ms})\end{array}$ \\
$\mathrm{y}$ & 277.20 & 175.30 & 72.40 & 13.86 & \\
$\mathrm{y}$ & 233.75 & 154.90 & 49.20 & 11.68 & 50.15 \\
\hline $\mathrm{T}$ & 283.90 & 178.35 & 75.80 & 14.19 & \\
\hline \multicolumn{7}{|c|}{ Initiator Current } & \multicolumn{2}{|c|}{$10.5 \mathrm{~A}$} \\
\hline
\end{tabular}

Berdasarkan hasil pengujian yang diperoleh, dapat diketahui lamanya waktu kerja OCO untuk fasa $\mathrm{R}$ adalah sebesar $277.20 \mathrm{~ms}$, pada fasa $\mathrm{S}$ yaitu $233.75 \mathrm{~ms}$, dan pada fasa T selama $283.90 \mathrm{~ms}$ dengan deviasi waktu tertinggi selama $50.15 \mathrm{~ms}$. Nilai deviasi waktu yang terjadi pada saat OCO tersebut terbilang sangat besar sehingga deviasi cycle pada PMT pun ikut membesar hingga mencapai 2.51 cycle. Penyebab besarnya deviasi waktu ini tentunya disebabkan oleh waktu kerja pada fasa $\mathrm{S}$ yang terlalu cepat dibandingkan dengan yang lainnya, walaupun jika dibandingkan hasil perolehan waktu kerja pada saat OCO ini dengan batas standar waktu maksimum yang diijinkan, waktu kerja pada pengujian ini masih dibawah batas yang diijinkan yaitu $\leq 300 \mathrm{~ms}$.

Lamanya waktu Contact Dead Time pada saat pengujian menghasilkan nilai waktu kerja untuk fasa $\mathrm{R}$ selama $175.30 \mathrm{~ms}$, pada fasa $\mathrm{S}$ selama $154.90 \mathrm{~ms}$, dan pada fasa $\mathrm{T}$ terjadi selama $178.35 \mathrm{~ms}$. Sedangkan untuk waktu Contact Live Time yang didapat yaitu $72.40 \mathrm{~ms}$ pada fasa $\mathrm{R}, 49.20 \mathrm{~ms}$ pada fasa $\mathrm{S}$, dan $75.80 \mathrm{~ms}$ pada fasa T. Dimana maksud dari Contact Live Time disini adalah lamanya waktu ketika kontak PMT dalam kondisi tertutup $(O N)$ sesaat ketika PMT bekerja untuk menutup kontaknya sebelum kemudian akan diikuti dengan pembukaan kontak yang dilakukan secara cepat oleh PMT atau dapat juga dikatakan Contact Live Time adalah lamanya waktu tunda (jeda) yang dibutuhkan oleh PMT untuk membuka kontaknya kembali sesaat setelah PMT baru selesai melakukan penutupan kontak sebelumnya.

Pada pemeliharaan dan pengujian waktu OCO ini, data hasil pengujian tidak dibandingkan dengan trend 3 kali pemeliharaan 2 tahunan yang lalu, karena dari tahun 2014 - 2018, tidak dilakukan pengujian waktu kerja OCO pada PMT Mandirancan I tersebut.

\section{E. Rekomendasi dan Solusi Temuan Anomali Waktu Tutup Kontak PMT}

Dalam melakukan pemeliharaan dan pengujian kecepatan waktu kerja dan keserempakan kontak PMT, tentunya tidak akan selalu memperoleh nilai waktu pengujian yang baik, ada kalanya ketika melakukan pengujian ditemukan gangguan dan permalasahan pada PMT tersebut. Dimana dalam kasus PMT Mandirancan I ini diketahui anomali besarnya selisih waktu kerja kontak PMT yang melebihi dari nilai standar yang ditentukan dan juga hasil waktu kerja kontak PMT pada fasa S yang terlalu cepat dibandingkan dengan kedua kontak pada fasa lainnya ketika melakukan operasi kerja untuk menutup kontaknya yang 
menyebabkan besarnya selisih deviasi waktu kerja pada PMT Mandirancan I tersebut.

Permasalahan kerja kontak yang telalu cepat ini biasanya muncul akibat kekuatan mekanik penggerak yang diberikan pada kontak PMT terlalu kuat sehingga kerja kontak menjadi lebih cepat daripada yang seharusnya. Dimana waktu kerja kontak yang terlalu cepat ini juga tidak baik karena dapat merusak kontak gerak dari PMT tersebut akibat dari hantaman yang terjadi pada kontak terlalu keras dan tidak sesuai standar, tentunya hal ini akan mengurangi umur masa pakai dari PMT tersebut. Untuk mengatasi hal ini salah satu caranya yaitu dengan memperbaiki dan melakukan pengaturan ulang pada mekanik penggerak yang dimiliki oleh PMT Mandirancan I agar waktu kerja pada PMT tersebut dapat kembali sesuai dengan batas waktu normal.

Dalam kasus PMT Mandirancan I ini ketika dilakukan investigasi penyebab dari permasalahan ini, ditemukan bahwa pada saat spring (pegas) PMT tersebut sedang melakukan pengisian ulang oleh motor di box kontrol PMT agar kembali ke kondisi spring Full Charge untuk melakukan proses penutupan kontak pada PMT tersebut, ternyata motor yang terdapat pada box kontrol PMT di kontak fasa S melakukan pengisian dengan waktu pengisian motor yang lebih lama dari kedua motor pada fasa lainnya, sehingga otomatis kekuatan mekanik penggerak dari spring (pegas) yang dimiliki oleh kontak PMT pada fasa S menjadi lebih kuat daripada kedua kontak pada fasa lainnya. Hal ini menyebabkan, ketika semua kontak PMT melakukan proses penutupan kontaknya, ketiga kontak PMT tersebut yang seharusnya menutup secara bersamaan menjadi tidak serempak, karena gaya dorong yang dimiliki oleh spring yang diisi lebih lama oleh motornya pada kontak PMT fasa $S$ memiliki gaya dorong spring yang jauh lebih besar dibandingkan dengan 2 kontak lainnya, sehingga kontak pada fasa $\mathrm{S}$ menjadi bekerja lebih cepat ketika menutup kontaknya.

Oleh karena itu, untuk mengatasi permasalahan tersebut, maka dilakukanlah penyetelan dari Motor Run Limit Switch yang dimiliki oleh PMT tersebut. Adapun maksud dari Motor Run Limit Switch ini adalah komponen saklar mekanis yang digunakan pada PMT untuk memutus aliran listrik pada motor penggerak pegas saat sedang melakukan pengisian mekanik penggeraknya secara otomatis ketika kondisi pegas sudah dalam keadaan Full Charge. Dimana dalam kasus PMT Mandirancan I ini karena pengaturan dari limit switch pada fasa $S$ berbeda dengan fasa $\mathrm{R}$ dan $\mathrm{T}$, maka perlu dilakukan pengaturan kembali pada gear penggerak yang menggerakkan tuas pada limit switch tersebut agar waktu ketika tuas mengaktifkan Motor Run Limit Switch pada PMT serupa dengan waktu kontak pada fasa lainnya, sehingga mekanik penggerak spring (pegas) pada tiap kontaknya memiliki kekuatan dan lama waktu pengisian pegas oleh motor yang sama.

\section{KESIMPULAN}

\section{A. Kesimpulan}

Setelah dilakukan pengujian pada PMT Single Pole $150 \mathrm{kV}$ Mandirancan I, berikut beberapa simpulan yang dapat disampaikan mengenai pengujian kelayakan operasi kerja pada PMT yang diamati melalui parameter dari alat ukur Breaker Analyzer.

1. Pengujian waktu kerja dan keserempakan yang dilakukan pada PMT $150 \mathrm{kV}$ Mandirancan I ada 4 macam jenis pengujian, yaitu antara lain pengujian waktu kerja kontak open, close, reclose, dan OCO (Open - Close Open).

2. Setelah dilakukan pengujian, didapati ternyata pada PMT Mandirancan I ini memiliki permasalahan anomali deviasi waktu yang cukup besar melebihi dari nilai standar yang ditentukan.

3. Penyebab dari besarnya deviasi waktu yang terjadi pada PMT Mandirancan I ini karena waktu kerja kontak PMT pada fasa S ketika melakukan operasi kerja untuk menutup kontaknya terlalu cepat jika dibandingkan dengan 2 fasa lainnya.

4. Anomali deviasi waktu yang besar ini disebabkan karena perbedaan lamanya waktu pengisian ulang pegas pada kontak oleh motor penggerak pegas di fasa $\mathrm{S}$ yang menyebabkan ketika kontak menutup kekuatan pegas pada fasa $\mathrm{S}$ 
menjadi lebih kuat dari kedua kontak lainnya karena pengisiannya yang lebih lama sehingga waktu kerja pada pada fasa $S$ menjadi lebih cepat.

5. Anomali deviasi waktu ini dapat menyebabkan kerusakan pada bagian dalam Interrupter PMT karena timbulnya busur api yang terlalu besar ketika waktu kerja kontak lambat dan jika terlalu cepat dapat merusak bagian Fix Contact maupun Moving Contact PMT akibat kekuatan yang diberikan oleh pegas terlalu besar. Hal ini pun dapat juga menyebabkan pembebanan berlebih pada salah satu fasa yang anomali tersebut sehingga dapat mengurangi masa umur pakai peralatan. Jika PMT tidak serempak pun dapat juga menimbulkan pergeseran titik netral apabila deviasi waktu kerja PMT terlalu besar.

6. Untuk mengatasi waktu kerja pada kontak fasa $\mathrm{S}$ ini, dilakukan perbaikan dan pengaturan ulang Motor Run Limit Switch pada PMT tersebut agar dapat memutus aliran listrik ke motor di waktu yang serupa dengan fasa lainnya sehingga mekanik penggerak pegas pada tiap fasanya memiliki kekuatan yang sama.

\section{B. Saran}

Saran yang dapat disampaikan terkait permasalahan pada PMT $150 \mathrm{kV}$ Mandirancan I ini, yaitu untuk sesegera mungkin melakukan perbaikan pada PMT tersebut ataupun bila perlu dilakukan penggantian dengan PMT unit baru karena usia pada PMT tersebut sudah terbilang cukup tua dan mengingat kasus anomali deviasi waktu ini telah terjadi pada PMT ini sejak tahun 2016 hingga sekarang, maka dari itu tindakan perbaikan yang cepat harus segera dilakukan agar dapat memperbaiki kualitas penyaluran dan tetap dapat menjaga tingkat keandalan serta kontinuitas dalam menyalurkan tenaga listrik ke konsumen.

\section{REFERENSI}

[1] D. Aribowo et al., "Analisis Hasil Uji PMT $150 \mathrm{kV}$ pada Gardu Induk Cilegon Baru BAY KS 1,” pp. 59-65, 2018.

[2] A. S. Pambudi, "Pengujian Keserempakan Pemutus Tenaga (PMT) Three Pole $150 \mathrm{kV}$ Bay Trafo Gardu Induk Simulator Udiklat Semarang (TLM Academy)," J. Tek. Elektro, p. 4, 2014.

[3] P. Nur and B. Winardi, "Pengujian Keserempakan Pemutus Tenaga (Pmt) 20 Kv Di Gardu Induk $150 \mathrm{Kv}$ Purbalingga Pt. Pln (Persero)," No. 024, Pp. 74600537460055, 2018.

[4] E. YULIANTO, "Pengujian Keserempakan Pemutus Tenaga $150 \mathrm{kV}$ di Bay Cep 1 dan 2 Gardu Induk Sunyaragi PT. PLN (Persero) APP Cirebon," 2017.

[5] A. Goeritno, S. Rasiman, and Z. Komara, "Kinerja Pemutus Tenaga Tegangan Tinggi Bermedia Gas $\mathrm{SF}_{6}$ Berdasarkan Sejumlah Parameter Diri," Eeccis, vol. 12, no. 2, pp. 104-111, 2018.

[6] S. Robaga, A. Setyo, I. Samsu, and E. Al, "Buku Pedoman Pemeliharaan Pemutus Tenaga," PT. PLN, pp. 1-61, 2009.

[7] R. L. Imani, S. Suprijadi, and A. Siswanto, "Analisis Hasil Over Houl Pemutus Tenaga (Pmt) 70kv Pada Bay Arjawinangun 2 Di PT PLN Persero App Cirebon Gi Kadipaten," Conf. Innov. Appl. Sci. Technol., vol. 1, no. 1, pp. 618-625, 2018.

[8] Vanguard, "Operating Instructions for the CT-6500 Series 2," 2008.

[9] Alstom, "Operating Instructions No . 195 A ( EN )," vol. 248, no. 195, pp. 1-128, 2005.

[10] PT. PLN (Persero). 2014, Buku Petunjuk Gardu Induk, SE No.0520-2.K/DIR/2014, PT. PLN (Persero), Jakarta.. 